\title{
LAMA PENYIMPANAN DAGING SAPI TERHADAP ALT BAKTERI
}

Insun Sangadji, Dosen Jurusan Peternakan, Fakultas Pertanian, Universitas Pattimura Ambon

E-mail: $\underline{\text { in_sangadji@yahoo.com }}$

\begin{abstract}
Abstrak: Penelitian dilaksanakan di Laboratorium MIPA Institut Agama Islam Negeri (IAIN) Ambon pada tanggal 15 April sampai 22 April 2013. Analisis data yang digunakan adalah kuantitatif dengan menggunakan uji ANOVA. Hasil penelitian inferensial dengan menggunakan uji ANOVA pada efek lama penyimpanan daging sapi terhadap total koloni bakteri, pada penyimpanan 0 hari memiliki nilai rata-rata 2353,25 x $10^{7}$ /gram daging sapi, sedangkan penyimpanan 1 hari memiliki nilai rata-rata $6,53 \mathrm{x}$ $10^{5}$, penyimpanan 2 hari nilai rata-rata 4,50 x $10^{4} /$ gram daging sapi, penyimpanan 3 hari nilai rata-rata $1,36 \times 10^{4} / \mathrm{gram}$ daging sapi. Ini menandakan daging semakin lama penyimpanan jumlah koloni bakteri makin sedikit karena resiko terkontaminasi daging biasanya berasal dari (RPH) rumah potong dan para pekerja. Data hasil penelitian dihitung dengan menggunakan uji-F, diperoleh nilai $\mathrm{F}_{\text {hitung }}=10,06$, dan $\mathrm{F}$, table $5 \%=3,59$ dan $1 \%=6,22$, sehingga $\mathrm{H}_{0}$ ditolak karna perlakuan memberikan berpengaruh terhadap variabel respons.
\end{abstract}

\section{Kata Kunci: Daging Sapi, Lama Penyimpanan, Koloni Bakteri}

\section{LONG STORAGE BEEF AGAINST ALT BACTERI}

\begin{abstract}
Research carried out in a laboratory MIPA IAIN Ambon on april 15 until april 22 2013. Kuantitatif analysis of date that we use is by using ANOVA test. An research result of inferential by using test ANOVA on the effects long storage beef to the total bacteria colonies, in storage 0 day having an average value 2353, $25 \times 10^{7} / \mathrm{gr}$ beef, while storage 1 day $6,53 \times 10^{5}$, having an average value storage two days, the average value of $4,50 \times 10^{4} / \mathrm{gr}$ beef, storage 3 days average value of $1,36 \times 10^{4} / \mathrm{gr}$ beef. It signifies meat the longer storage the amount of bacteria colonies less because the risk contaminated meat usually derived from slaughterhouse and the workers. The results of the research calculated by applying $\mathrm{F}$ test, obtained the value of $\mathrm{F}$ count $=10,06$ and $\mathrm{F}$, table $5 \%=$ 3,59 and $1 \%=6,22$, so that treatment $\mathrm{H}_{0}$ rejected because to give impact on variable response.
\end{abstract}

Keywords: Beef, Long storage, Bacteria Colonies. 
Kebutuhan masayarakat Indonesia akan gizi menuntut dikembangnya berbagai industri pangan. Salah satu sektor turut berperan penting dalam ketersediaan bahan pangan adalah sektor peternakan, karna nilai gizinya yang tinggi, sehingga konsumsi di masayarakat masih tinggi. Pangan asal ternak yang cukup digemari oleh masayarakat adalah daging sapi. Kebutuhan masayarakat akan daging sapi yang semakin meningkat menututut menyebabkan produsen daging sapi harus memperhatikan kualitas daging sapi saat siap akan dipasarkan sehinga daging sapi siap dan aman dikonsumsi. Daging sapi mengandung zat gizi yang tinggi terutama proteinya dengan komposisi asam amino yang seimbang dan bermanfaat bagi tubuh manusia. Kandungan gizi yang tinggi meyebabkan daging mempunyai sifat mudah rusak (perishable) karena mikrooganisme dapat tumbuh dan berkembang biak di dalamnya. Salah satu mikroorganisme perusak adalah bakteri (Cicilia Takasari, 2008).

Bakteri adalah mikroorganisme bersel satu berkembang biak dengan cara membelah diri dan hidup pada bahan yang beraktifitas air yang tinggi. Bakteri yang bersifat aerob (bakteri yang hidup memerlukan oksigen), anaerob (bakteri yang hidup tidak memerlukan oksigen). Awal kontaminasi pada daging bersal dari mikroorganisme yang memasuki peredaran darah pada saat penyembelihan, jika alat-alat yang digunakan tidak steril. Kontaminasi selanjutnya dapat terjadi pada permukaan daging selama operasi persiapan daging yaitu: proses pembelahan daging, pendinginan, pemotongan daging, jadi segala sesuatu yang dapat berkontak dengan daging secara langsung atau tidak langsung, bisa merupakan sumber kontaminasi bakteri (Soeparno,2009).

Pengaruh penyimpanan juga berpengaruh terhadap kualitas daging, Penyimpanan daging sapi pada daerah terbuka dapat menyebabkan daging terkontaminasi oleh bakteri dengan mudah, namun seperti yang kita ketahui bersama bahwa bakteri tidak dapat di musnakan tapi dapat di kurangi jumlahnya. Penyimpanan daging di dalam pendingin pada suhu yang beku akan membuat daging terkontaminasi oleh bakteri tapi penyimpanan pada suhu di bawah suhu lima derajat akan mengurangi jumlah bakteri. Penyimpanan daging pada suhu dingin, meskipun dalam waktu yang singkat, diperlukan untuk mengurangi kontaminasi bakteri (Hufri. Yant, Hidayanti, \& Elfawati, 1989).

Adapun masalah dalam penelitian ini adalah:

1. Apakah ada pengaruh pertumbuhan total koloni bakteri pada daging sapi dengan penyimpanan yang berbeda?

2. Berapa besar pertumbuhan bakteri pada lama penyimpanan yang berbeda.?

Tujuan dari penelitian ini adalah:

1. Untuk mengetahui seberapa besar pertumbuhan total koloni bakteri pada daging sapi dengan lama penyimpanan yang berbeda.

2. Untuk mengetahui pengaruh lama penyimpanan terhadap total koloni bakteri.

\section{METODE PENELITIAN}


Jenis penelitian yang digunakan adalah penelitian kuantitatif dengan pendekatan eksperimen laboratorium menggunakan Rancangan Acak Lengkap (RAL) dengan 4 perlakuan dan 4 kali ulangan untuk melihat pengaruh lama penyimpanan terhadap total koloni bakteri. Penelitian ini terdiri dari dua variabel yaitu: lama penyimpanan daging sapi sebagai variabel bebas, dan total koloni bakteri sebagai variabel terikat.

Alat-alat yang digunakan dalam penelitian ini adalah: Timbangan, Tabung reaksi, Cawan petri, Mikro pipet, Incubator, Stanggel stick, Lampu bunsen, Forteks, Gelas ukur, Spatula, Hot plate, Autoclave, Lumpang dan alu, Pinset, Erlenmeyer, Pipet tetes. Bahanbahan yang digunakan dalam penelitian ini adalah: Sampel daging sapi, nutrien agar, aquades, dan kapas.

\section{Pembuatan sampel}

a. Pengambilan sampel dari rumah potong(RPH) batu merah kota ambon sebanyak $1 \mathrm{~kg}$.

b. Daging sapi dibagi menjadi 16 potong (sesuai jumlah sampel) kemudian di bungkus dengan menggunakan plastik.

c. Simpan daging dalam pendingin yang bersuhu berkir $3^{0} \mathrm{C}$ derajat celcius sesuai lama penyimpanan.

\section{Pembuatan pengenceran}

a. Untuk uji pertama ambil daging yang penyimpanan 0 hari

b. Daging dihaluskan menggunakan lumpang dan alu.

c. Ambil sampel yang telah dihaluskan dengan menggunakan spatula lalu timbang dengan menggunakan timbangan analitik sebanyak 10 gram.

d. Ambil daging dengan menggunakan pinset dan kemudian masukkan ke dalam botol yang sudah berisi aqudes sebanyak $150 \mathrm{ml}$.

e. Kemudian membuat campuran menjadi homogen dengan menggunakan vorteks.

f. Membuat pengenceran menyiapkan 2 buah tabung reaksi dan 24 buah buah erlenmeyer yang berukuran $150 \mathrm{ml}$, dan gelas ukur yang berukuran $5 \mathrm{ml}$ serta gelas kimia.

g. Mengukur volume aquades dari gelas kimia ke dalam gelas ukur dengan menggunakan pipet tetes.

h. Menuangkan aqudes dari gelas ukur ke dalam tabung reaksi(1 tabung memerlukan 9 $\mathrm{ml}$ larutan aquades untuk pengenceran) kemudian tutup mulut masing-masing dengan kapas.

i. untuk pengenceran stok memerlukan larutan aqudes sebanyak $90 \mathrm{ml}$ dan masukkan ke dalam gelas erlenmeyer setelah itu menutup mulut gelas dengan kapas.

\section{Tahap pembuatan media}


a. Menyiapakan media agar (NA) Nutrien agar. Dengan cara menimbang NA sebanyak 23 gram dan menuangkanya kedalam gelas erlenmeyer yang suda terisi dengan aqudes sebanyak $1000 \mathrm{ml}$.

b. Panaskan larutan NA (Nutrien Agar) diatas hotplate sambil diaduk dengan menggunkan batang pengaduk sehingga mendidih setelah mendidih angkat dan tutup mulut gelas menggunakan aluminium foil.

c. Memasukkan bahan-bahan yang sudah disiapkan yaitu larutan pengenceran dan larutan media nutrien agar kedalam autoclave selama 1 jam.

d. Kemudian untuk uji yang pertama yaitu daging sapi yang belum disimpan yaitu 0 hari.

e. Setelah itu menghaluskan daging sapi dengan menggunakan lumpang dan alu.

f. Daging sapi yang telah dihaluskan ditimbang sebanyak 10 gram dengan menggunakan timbangan analitik.

g. Masukan daging sapi kedalam botol yang sudah berisi aquades sebanyak $150 \mathrm{ml}$ dan campur cairan menjadi homogen dengan menggunakan forteks.

h. Masukan media nutrien agar ke dalam erlenmeyer yang suda diisi dengan aquades

i. Panaskan media yang telah dicampur dengan aquades dengan menggunakan hot plate

4. Penanaman sampel

a. Menyiapkan ekstrak daging sapi dari masing- masing pengenceran $1 \mathrm{ml}$ dengan menggunakan mikro pipet dan menuangkan ke dalam16 buah cawan petri yang mengisikan media Nutriet agar (NA).

b. Selanjutnya pengenceran $10^{-4}, 10^{-5}$, dan $10^{-6}$ diambil sebanyak $1 \mathrm{ml}$ dan masukkan ke dalam 16 buah cawan petri yang telah terisi media NA dengan menggunakan mikro pipet dan mencantumkan lebel pada masing-masing cawan petri sesuai dengan lebel pengenceran yang dimasukan ke dalam cawan petri tersebut (pengenceran $10^{-4}, 10^{-5}$, dan $10^{-6}$ )

c. Setelah itu media diratakan dengan menggunakan batang penyebar, pada saat penelitian harus didekat api bunsen agar tetap steril dan dapat mengurangi kontaminasi terhadap bakteri.

d. Kemudian 16 buah cawan petri dimasukkan ke dalam inkubator selama 24 jam

5. Tahap Perhitungan

a. Tahap akhir yaitu setelah 24 jam cawan petri dikeluarkan dari incubator dan dihitung total koloni bakteri yang tumbuh.

b. Tahap pelaksaanan di atas akan dilakukan pada penelitian daging sapi dengan lama penyimpanan yang berbeda yang akan diuji dengan melakukan prosedur kerja yang sama sesuai dengan urutan prosedur.

Data diperoleh hari perhitungan total bakteri pada daging sapi yang disimpan dengan lama penyimpanan sesuai perlakuan. Data yang diperoleh dari hasil perhitungan 
total koloni bakteri dianalisis dengan menggunakan uji ANOVA pada taraf signifikan 5\% jika ada pengaruh maka dilanjutkan dengan uji BNT.

\section{HASIL DAN PEMBAHASAN}

Tabel 1 Total Koloni Bakteri pada Daging Sapi dengan Lama Penyimpanan yang Berbeda.

\begin{tabular}{|c|c|c|c|c|c|c|}
\hline \multirow{2}{*}{ Perlakuan } & \multicolumn{4}{|c|}{ Ulangan } & \multirow{2}{*}{$X$} & \multirow{2}{*}{ Rata-rata } \\
\hline & 1 & 2 & 3 & 4 & & \\
\hline 0 hari & $4263 \times 10^{5}$ & $2655 \times 10^{5}$ & $795 \times 10^{5}$ & $1700 \times 10^{5}$ & $9413 \times 10^{5}$ & $8327 \times 10^{5}$ \\
\hline 1 hari & $25,5 \times 10^{5}$ & $0,1 \times 10^{5}$ & $0 \times 10^{5}$ & $0,5 \times 10^{5}$ & $26,1 \times 10^{5}$ & $6,553 \times 10^{5}$ \\
\hline 2 hari & $1,55 \times 10^{5}$ & $0,1843 \times 10^{5}$ & $0,015 \times 10^{5}$ & $0,05 \times 10^{5}$ & $1,7993 \times 10^{5}$ & $0,445 \times 10^{5}$ \\
\hline 3 hari & $0,1793 \times 10^{5}$ & $0,05 \times 10^{5}$ & $0,084 \times 10^{5}$ & $0,2288 \times 10^{5}$ & $0,5421 \times 10^{5}$ & $0,136 \times 10^{5}$ \\
\hline
\end{tabular}

Perbedaan jumlah koloni pada setiap perlakuan disebabkan bakteri akan mati pada suhu dingin dan suhu titik beku jadi, semakin lama penyimpanan jumlah bakteri yang terkandung dalam daging akibat terinfeksi semakin menurun.

Tabel 2 Hasil Uji ANOVA Total Koloni Bakteri dengan Lama Penyimpanan yang Berbeda

\begin{tabular}{|c|c|c|c|c|c|c|}
\hline \multirow[t]{2}{*}{ SUMBER KERAGAMAN } & \multirow[b]{2}{*}{ DB } & \multirow[b]{2}{*}{ JK } & \multirow[b]{2}{*}{ KT } & \multirow[b]{2}{*}{ F. hitung } & \multicolumn{2}{|c|}{$\mathrm{F}_{\text {table }}$} \\
\hline & & & & & $5 \%$ & $1 \%$ \\
\hline Perlakuan & 3 & 16580012 & 5526670,7 & \multirow{3}{*}{10,06} & \multirow{3}{*}{3,59} & \multirow{3}{*}{6,22} \\
\hline Galat & 11 & 6594353 & 549529,42 & & & \\
\hline Total & 15 & 23174365 & 1544957,7 & & & \\
\hline
\end{tabular}

Keputusan uji anova pada taraf signifikan 5\% $\mathrm{F}_{\text {hitung }}>F_{\text {tabel }}$ artinya tidak berpengaruh terhadap pertumbuhan bakteri pada gaging sapi yang diuji. Daging sapi mengandung protein yang sangat dibutuhkan oleh tubuh, protein esensial sangat dibutuhkan dalam proses metabolisme tubuh manusiaSetelah dilakukan penelitian perhitungan uji-F untuk melihat total koloni bakteri yang tumbuh pada daging sapi setelah lama penyimpanan yang berbeda, diperoleh nilai $\mathrm{F}$ hitung 10,06 $>\mathrm{F}$ tabel. Oleh karena itu, $\mathrm{H}_{0}$ ditolak karena perlakuan memberikan pengaruh signifikan terhadap variable respons.

\section{Daging sapi untuk lama penyimpanan 0 hari}

Daging sapi untuk lama penyimpanan 0 hari, memiliki warna masih segar, tekstur yang masih kenyal, dan warna daging masih mengelurkan darah karena baru diambil dari tempat potong. Setelah di lakukan penelitian untuk melihat bakteri dalam bentuk sejumlah koloni yang tumbuh pada media nutriet agar (NA) yang telah ditanami larutan pengenceran yaitu aquades ditambah dengan daging sapi yang sudah dihaluskan dan ditanami pada media NA adalah pengenceran $10^{-4}$ yang berjumlah 432,5 pada pengenceran $10^{-5}$ berjumlah 142,5 dan pengenceran $10^{-6}$ bejumlah 71 dan telah di inkubasi selama 24 jam terlihat bahwa koloni- koloni bakteri tumbuh dengan pesat, pada penelitian 0 hari diperoleh nilai rata-rata $2353,25 /$ gr daging sapi. 
Hal ini disebabkan karena daging pada penyimpanan 0 hari terkontaminasi permukaan daging saat penyembelihan dirumah potong (RPH) sumber kontaminasi dapat berasal dari dari tanah sekitar, air, dan alat-alat yang digunakan selama proses penyembelihan. Permukaan daging segar yang berhubungan dengan udara akan menguntungkan bagi bakteri aerobik (tumbuh tanpa memerlukan oksigen) Soeparno, (2009). Penyimpanan daging sapi 0 hari pertumbuhan total koloni yang tumbuh sudah melewati angka Standar Nasional Indonesia yang menjelaskan bahwa batas jumlah mikroba pada daging tidak melebihi $10^{5} \mathrm{CFU}$

\section{Daging sapi untuk 1 hari penyimpanan}

Saat penyimpanan daging sapi selama 1 hari daging masih telihat segar, teksturnya mulai sedikit mengeras, aroma dan warna pada daging sedikit pucat dan tidak mengeluarkan darah karena penyimpanan pada suhu dingin, Pada saat dilakukan penelitian atau uji coba terhadap pertumbuhan bakteri jumlah bakteri yang tumbuh lebih sedikit dari 0 hari, untuk penyimpanan 1 hari setelah dilakukan penelitian bahwa setiap pengenceran yang ditanami pada media NA ditumbuhi sejumlah bakteri yang akan diuraikan berikut ini: untuk penyimpanan 1 hari nilai rata-rata jumlah koloni yang tumbuh yaitu $6,53 \times 10^{5} / \mathrm{gr}$ daging sapi.

Penyimpanan daging sapi 1 hari tedapat perubahan dari, tekstur,dan warna daging serta pertumbuhan bakteri dengan ditandai sejumlah koloni pada permukaan cawan petri yang berisikan media NA yang telah diisolasi sampel yaitu larutan daging sapi. Disebabkan suhu dan tempat penyimpanan, bakteri bisa tumbuh pada suhu tertentu dan akan mati pada suhu tertentu, serta kelembapan yang semakin tinggi atau aktivitas air (AW), oksigen juga mempengaruhi pertumbuhan mikroorganisme (Anonim, 2007).

\section{Daging sapi untuk penyimpanan 2 hari}

Penyimpanan 2 hari daging sapi sudah telihat kualitas dari daging mulai menurun, daging sapi waktu dihaluskan sudah sedikit mengeras, aroma tidak segar. Pada penelitian ini jumlah koloni yang tumbuh semakin berkurang dibandingkan penyimpanan 0 hri dan 1 hari, untuk penyimpanan 2 hari diperoleh nilai rata-rata jumlah koloni sebanyak 0,445 x $10^{5} /$ gr daging sapi. Penyimpan daging sapi selama 2 hari terdapat perubahan dari segi kualitas daging. Serta pertumbuhan bakteri, penyimpanan daging dalam pendingin pada suhu 3 derajat celcius akan membunuh pertumbuhan mikroorganisme, dan penyimpanan pada suhu dingin dapat mengurangi kualitas daging, keempukan dan warna daging. Temperatur dibawah kira-kira $3{ }^{0} \mathrm{C}$ dapat menghambat pertumbuhan mikroorganisme perusak atau pembusuk dan mencegah hampir semua bakteri patogen (Soeparno,2009).

\section{Daging sapi untuk penyimpanan 3 hari}

Penyimpanan 3 hari adalah penyimpanan diatas rata-rata dan selama penyimpanan itu dapat terlihat bahwa daging sudah tidak empuk, saat dihaluskan tekstur 
daging mengeras, dan warna daging berwarna pucat. Pada penyimpanan 3 hari terlihat jumlah total koloni bakteri menurun pesat. Setelah diuji dengan cara yang sama yang dilakukan pada daging sapi dengan lama penyimpanan 0 hari, 1 hari, dan 2 hari yaitu dengan pengenceran $10^{-1}, 10^{-2}, 10^{-3}, 10^{-3}, 10^{-4}, 10^{-5}$ dan $10^{-6}$ dan pengenceran $10^{-4}, 10^{-5}$, $10^{-6}$ yang ditanami pada media Nutriet Agar (NA) untuk lebih jelas seberapa besar pertumbuhan bakteri yang tumbuh dengan ditandai koloni-koloni yang tumbuh pada media dan diinkubasi selama 24 jam untuk penyimpanan 3 hari nilai rata-ratanya adalah $0,136 \times 10^{5}$ /gr daging sapi.

Terlihat jelas pertumbuhan bakteri dalam hal ini jumlah koloni jauh lebih sedikit dibandingkan dengan penyimpanan 0 hari, 1 hari, dan 2 hari. Untuk penyimpanan 3 hari atau penyimpanan diatas rata-rata sudah diketahui kualitas dari daging sapi, makin lama penyimpanan makin sedikit jumlah pertumbuhan jumlah koloni bakteri, suhu yang dipakai untuk tahap penyimpanan adalah suhu $3^{\circ} \mathrm{C}$ pada suhu ini dapat mematikan bakteri disamping itu kualitas dari daging sapi tersebut menurun, tapi masih layak dikonsumsi oleh manusia (Cicilia Takasari,2008).

Kualitas mikrobiologis daging sangat dipengaruhi oleh banyak hal antara lain adalah cara pemotongan, penyimpanan, pengemasan, distribusi, pengolahan, dan cara mengkonsumsi daging tersebut. Titik kritis kontaminasi mikroorganisme pada daging terletak pada cara pemotongannya di Rumah Potong Hewan (RPH). Kontaminasi umumnya berasal dari peralatan yang digunakan saat pemotongan, cara pemotongan, dan kontaminasi dari pekerja Rumah Potong Hewan (RPH). Penanganan di Rumah Potong Hewan (RPH) yang kurang hegenis menyebabkan kontaminasi paling besar pada daging sapi segar.

Pecegahan kontaminasi dapat dilakukan melalui penekanan jumlah mikroorganisme dalam daging. Hal ini karena selain dari Rumah Potong Hewan (RPH), kontaminasi pada daging juga disebabkan saat distribusi dan penjualan daging yang berasal dari udara terbuka, peralatan yang digunakan, suhu saat distribusi dan penjualan (Soeparno, 2009).

\section{KESIMPULAN}

1. Pada penelitian dengan menggunakan daging sapi dengan lama penyimpanan yang berbeda terdapat perbedaan jumlah total koloni, dimana rata-rata jumlah total koloni pada perlakuan 0 hari memiliki total koloni 2353, $25 \times 10^{5}$ /gr daging sapi lebih besar dari lama penyimpanan pada perlakuan 1, 2, 3 hari, dimana perlakuan 3 hari memiliki rata- rata total koloni $0,136 \times 10^{5} / g r$ daging sapi, ini menandakan semakin lama penyimpanan semakin sedikit jumlah total koloni bakteri pada daging sapi.

2. Pertumbuhan total koloni bakteri pada daging sapi dipengaruhi oleh lamanya penyimpanan. 


\section{SARAN}

1. Diperlukan penelitian lanjutan tentang perbandingan daging rebus dengan daging segar dalam menghitung jumlah total koloni, karena penelitian yang dilakukan ini hanya berbatas pada sampel segar.

2. Lama penyimpanan yang berbeda dengan suhu yang sama menjadi faktor yang mempengaruhi pertumbuhan bakteri maka disarankan agar melakukan penelitian lanjutan tentang penyimpanan dalam jangka waktu panjang pada suhu titik beku.

\section{DAFTAR PUSTAKA}

Pane ismed. 1986. Pemamabiakan ternak sapi. Gramedia Pustaka utama. Jakarta

Soeparno. 2009. Ilmu dan teknologi daging. Gajah Mada Univesrsity. Yogyakarta

Maulana Rizky dan Amelia Putri. 2001. Kamus modern bahasa indonesia. Lima bintang. Surabaya.

Sugeng Bambang, 1992. Sapi potong. Penebar Swadaya. Jakarta

Takasari Cicilia. 2013. Kualitas Mikrobiologi Daging sapi segar dengan penambahan bakteriosin dari lactobacillus sp. Galur scg 1223 yang di isolasi dari daging sapi. (PDF jurnal) hlm 1-9, diakses tgl 22 Maret 2012.

Hafri Yanti, Hidayanti dan Elfawat. 2008. Kualitas daging sapi dalam kemasan PE di pasar pecan baru. (PDF jurnal) hlm 22, diakses pada tgl 17 Maret 2012. 